\title{
Connective tissue growth factor is induced in bleomycin-induced skin scleroderma
}

\author{
Shangxi Liu $\cdot$ Reza Taghavi $\cdot$ Andrew Leask
}

Received: 28 July 2009 / Accepted: 22 October 2009 /Published online: 15 November 2009

(C) The Author(s) 2009. This article is published with open access at Springerlink.com

\begin{abstract}
The origin of fibrotic cells within connective tissue is unclear. For example, the extent to which microvascular pericytes contribute to the number of myofibroblasts present in dermal fibrosis in uncertain. Connective tissue growth factor $(\mathrm{CTGF} / \mathrm{CCN} 2)$ is a marker and mediator of fibrosis. In this report, we use an antibody recognizing $\mathrm{CCN} 2$ to assess the cell types in mouse dermis which express CCN2 in the bleomycin model of skin scleroderma. Control (PBS injected) and fibrotic (bleomycin-injected) dermis was examined for $\mathrm{CCN} 2, \alpha$-smooth muscle actin ( $\alpha$-SMA) (to detect myofibroblasts), and NG2 (to detect pericytes) expression. Consistent with previously published data, CCN2 expression was largely absent in the dermis of control mice. However, upon exposure to bleomycin, CCN2 was observed in the dermis. Cells that expressed CCN2 were $\alpha$-SMA-expressing myofibroblasts. Approximately $85 \%$ of myofibroblasts were NG2-positive, CCN2-expressing pericytes, indicating that pericytes significantly contributed to the presence of myofibroblasts in sclerotic dermis. Thus $\mathrm{CCN} 2$ is induced in fibrotic skin, correlating with the induction of myofibroblast induction. Moreover, CCN2expressing pericytes significantly contribute to the appearance of myofibroblasts in bleomycin-induced skin scleroderma.
\end{abstract}

Keywords CTGF - CCN2 - Connective tissue growth factor Scleroderma $\cdot$ Fibrosis $\cdot$ Pericyte

S. Liu $\cdot$ R. Taghavi $\cdot$ A. Leask $(\bowtie)$

CIHR Group in Skeletal Development and Remodeling, Division of Oral Biology and Department of Physiology and Pharmacology, Schulich School of Medicine and Dentistry, Dental Sciences Building, University of Western Ontario, London, ON N6A 5C1, Canada

e-mail: Andrew.Leask@schulich.uwo.ca

\section{Introduction}

Tissue repair involves the reconstitution of connective tissue by a specialized from of fibroblast, termed the myofibroblast (Tomasek et al. 2002). This cell type is characterized by the expression of the pro-contractile protein $\alpha$-smooth muscle actin ( $\alpha$-SMA). Fibrosis can be considered to arise due to a persistence of the tissue repair program. Indeed, fibrotic lesions are populated large numbers of myofibroblasts (Desmouliere et al. 2005). Moreover, fibroblasts isolated from lesions of scleroderma patients show a persistently activated myofibroblast phenotype (Chen et al. 2005). The exact origin of myofibroblasts in tissue repair and fibrosis is unclear, but a significant percentage of may derive from pericytes surrounding blood vessels or from local recruitment of fibroblasts (Hinz et al. 2007; Rajkumar et al. 2006). For example, recently we found that, in cutaneous wounds in mice, approximately $30 \%$ of the myofibroblasts were also pericytes (Kapoor et al. 2008). However, the extent to which pericytes contribute to skin fibrosis is unclear.

CCN2 (Connective tissue growth factor/CCN2) is a member of the $\mathrm{CCN}$ family of proteins (Leask and Abraham 2006). CCN2 is an adhesive protein which acts through integrins and heparan sulfate-containing proteoglycans (HSPGs) (Lau and Lam 1999; Gao and Brigstock 2004). CCN2 is expressed in mesenchymal cells during development and wound healing, and is characteristically over-expressed in fibrotic diseases (Blom et al. 2002; Leask and Abraham 2006). The majority of studies on $\mathrm{CCN} 2$ gene regulation have been conducted in cell culture; for example, in fibroblasts, CCN2 is induced by transforming growth factor $\beta$ through Smads, ets- 1 and 
ras/MEK/ERK (Holmes et al. 2001; Leask et al. 2003; van Beek et al. 2006). CCN2 overexpression in dermal fibroblasts isolated from scleroderma patients, in contrast, is independent of TGF $\beta$ signaling and dependent on endothelin-1 and Sp1 (Holmes et al. 2003; Shi-Wen et al. 2007). In vivo, CCN2 is not normally expressed in adult mouse dermis, but is induced in myofibroblasts post-wounding (Kapoor et al. 2008). However, the whether the appearance of CCN2 correlates with myofibroblast induction in skin fibrosis is unknown.

Although mouse model perfectly recapitulates the characteristics of scleroderma, the bleomycin model skin fibrosis is often used as a model of scleroderma $(\mathrm{Wu}$ and
Varga 2008). CCN2 mRNA is induced in bleomycininduced lung fibrosis (Lasky et al. 1998; Ponticos et al. 2009), but whether CCN2 protein is induced in response to bleomycin-induced dermal fibrosis is unclear. Moreover, the cell types within the dermis that express CCN2 in response to bleomycin is unknown.

In this study, we subject mice to the bleomycin-induced model of skin scleroderma. We investigate the expression of CCN2 using an anti-CCN2 antibody. We also detect the presence of myofibroblasts and pericytes using appropriate markers. Hence, we provide a first careful analysis of the cell types expressing CCN2 in skin and generate new insights into the origin of myofibroblasts during skin fibrosis.

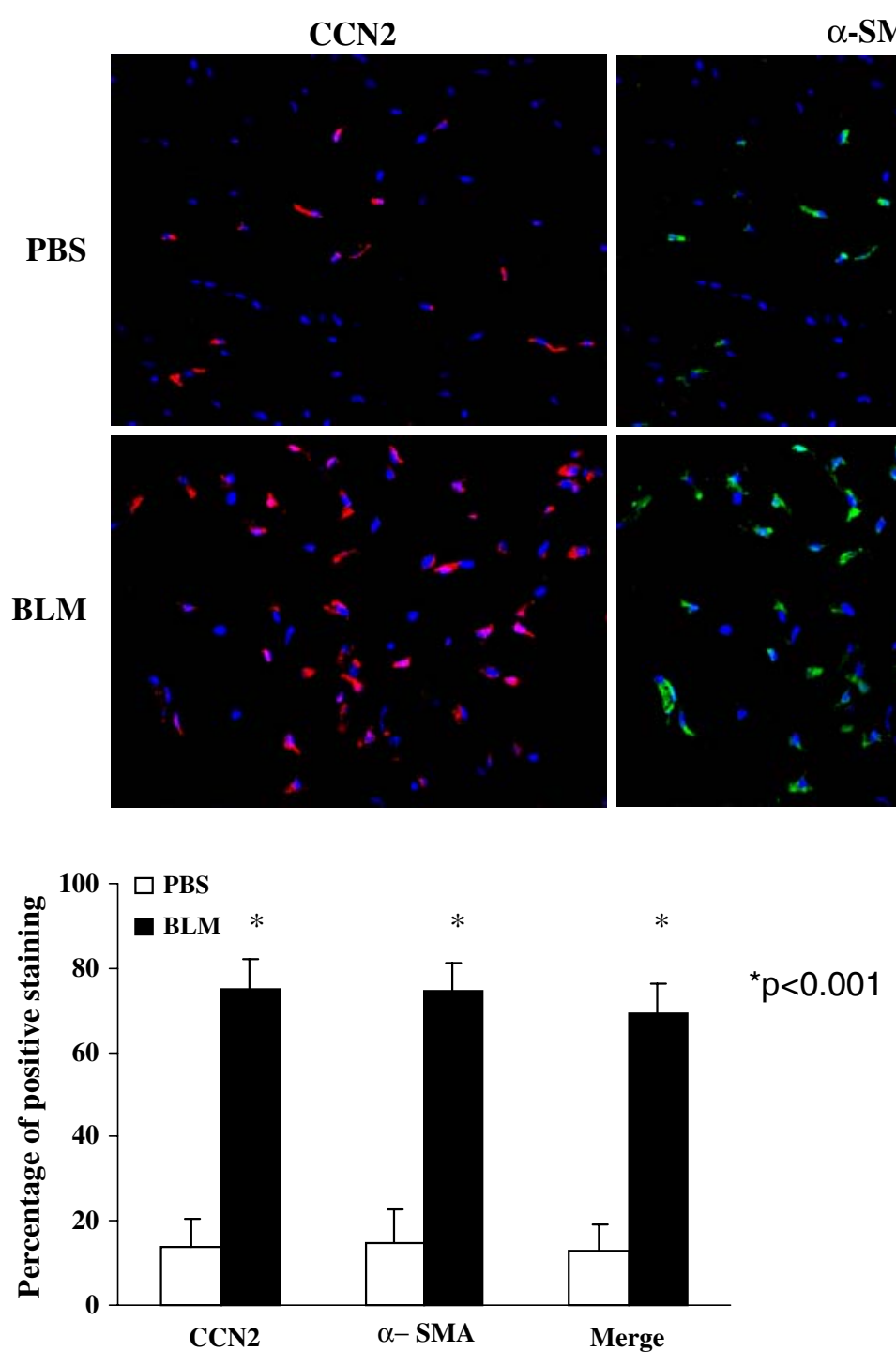

Fig. $1 \mathrm{CCN} 2$ promoter is expressed in myofibroblasts in response to bleomycin. Skin of mice treated with PBS or bleomycin was fixed, sectioned, and stained with DAPI to detect nuclei, anti- $\alpha$-SMA antibody to detect myofibroblasts and anti-CCN2 promoter antibody $(10 \times$

magnification of dermal tissue). The percentage of fibroblasts within the wound that were $\alpha-\mathrm{SMA}$ positive, CCN2- positive, and CCN2/ $\alpha$-SMA positive was calculated as described in Methods. Representative data from $n=4$ wounds from 4 separate animals are shown 


\section{Results}

CCN2 is induced in myofibroblasts in response to bleomycin

The cell types expressing CCN2 in fibrosis are unclear. To address this issue, C57/BL6 mice were subjected to subcutaneous injections of PBS or bleomycin over 28 days. As we were interested in the expression of $\mathrm{CCN} 2$ in connective tissue and in the origin of myofibroblasts within connective tissue, we focused our studies specifically on the dermis. When control PBS-injected skin was examined, a few CCN2positive cells were detected in the dermis (Fig. 1, CCN2, PBS). Conversely, in response to bleomycin, CCN2 expres- sion was strongly induced in the dermis (Fig. 1, CCN2, bleo). Similar patterns of expression were observed when tissue sections were stained with anti- $\alpha$-SMA antibody to detect the presence of myofibroblasts (Fig. 1, $\alpha$-SMA). Cells expressing CCN2 were also $\alpha$-SMA positive (Fig. 1, merge). Collectively, these data indicate that $\mathrm{CCN} 2$ is expressed in myofibroblasts in response to bleomycin.

$\mathrm{CCN} 2$ is expressed in pericytes post-bleomycin treatment

To assess the precise contribution of pericytes to the activated fibroblasts present in skin in response to bleomycin and to investigate whether $\mathrm{CCN} 2$ promoter was expressed pericytes, we performed double immunolabeling of tissue
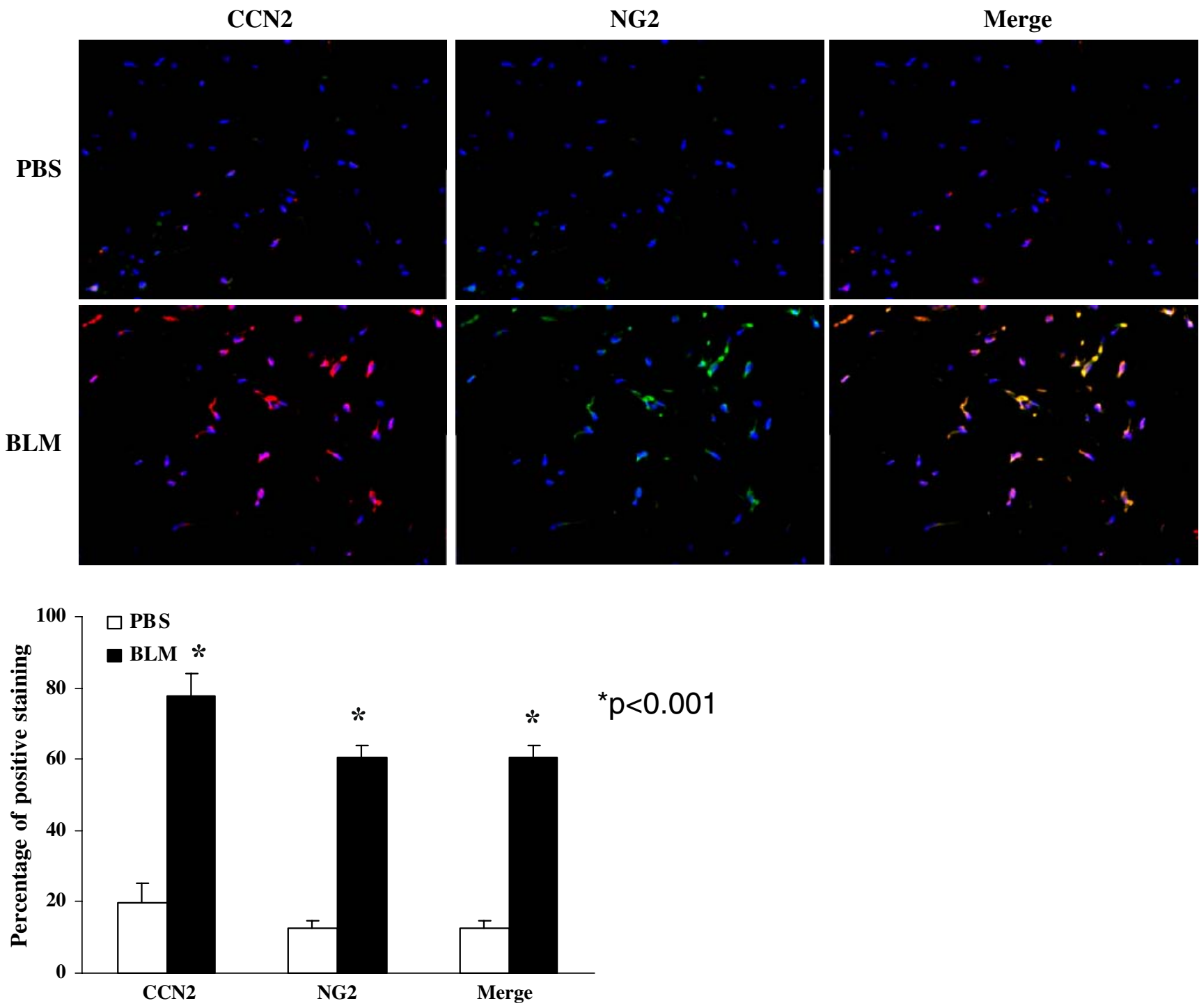

Fig. $2 \mathrm{CCN} 2$ promoter is expressed in pericytes in response to bleomycin. Skin of mice treated with PBS or bleomycin was fixed, sectioned, and stained with DAPI to detect nuclei, anti-NG2 antibody to detect myofibroblasts and anti-CCN2 antibody (10× magnification

of dermal tissue). The percentage of fibroblasts within the wound that were CCN2 positive, NG2 positive, and both NG2/CCN2-positive was calculated as described in Methods. Representative data from $n=4$ wounds from 4 separate animals per time point is shown 
sections with an anti-CCN2 antibody and an anti-NG2 antibody to detect pericytes. NG2 is routinely used a pericyte-specific marker in the literature (Ozerdem and Stallcup 2004; Salvucci et al., 2009 and references therein). We found that $60 \%$ of the cells in the tissue were NG2-expressing pericytes (Fig. 2). Double-labeling experiments revealed that $\mathrm{CCN} 2$ was expressed in pericytes (Fig. 2).
The majority of the myofibroblasts in bleomycin-induced skin scleroderma are pericytes

To assess whether pericytes contributed to the number of myofibroblasts in bleomycin-induced fibrotic tissue, tissue sections were stained with both anti-NG2 and anti- $\alpha$-SMA antibodies. In response to bleomycin, $\sim 75 \%$ of the cells in the tissue were both NG2-positive and $\alpha$-SMA positive
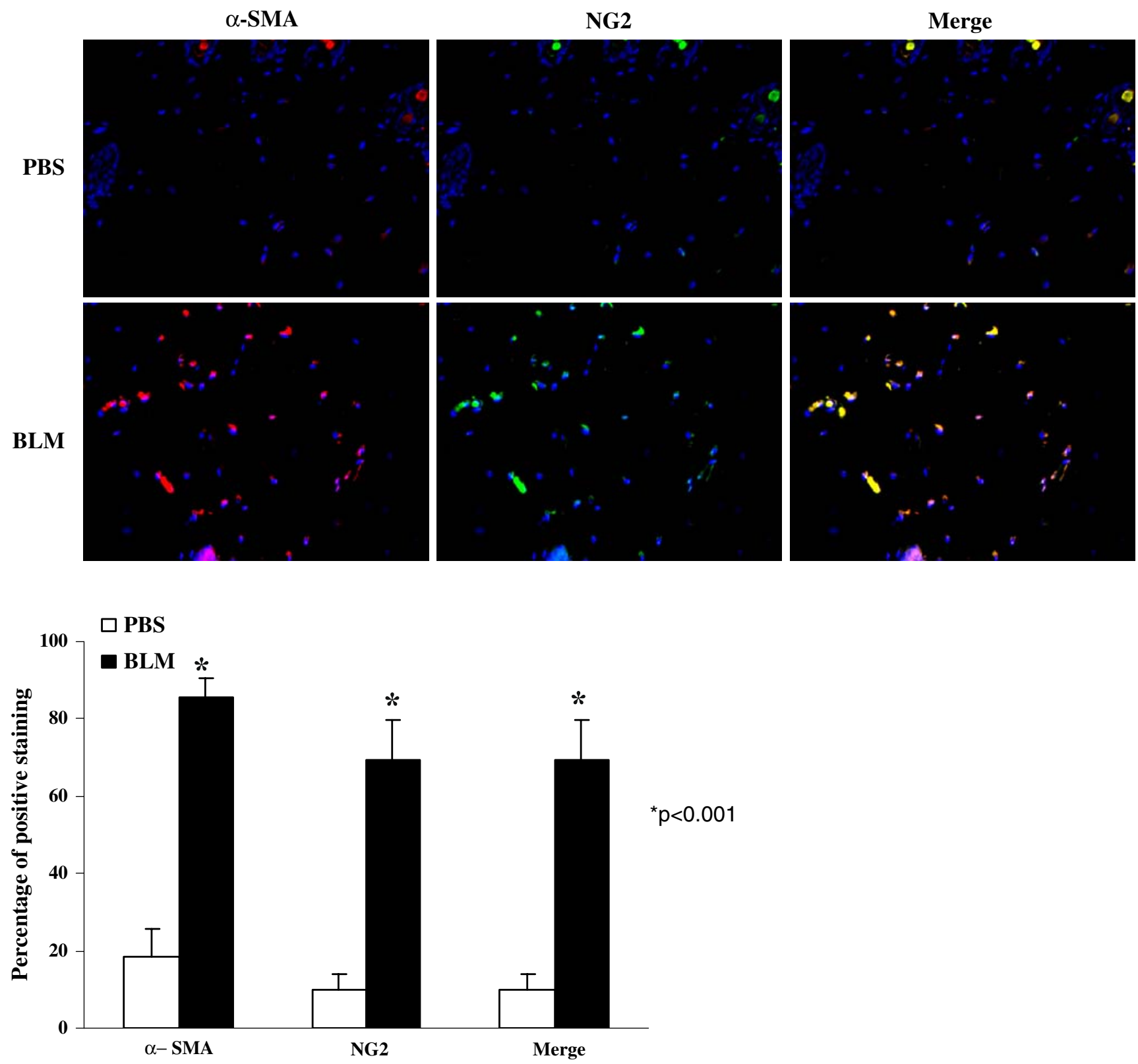

Fig. 3 A subset of myofibroblasts are perictyes in response to bleomycin. Skin of mice treated with PBS or bleomycin was fixed, sectioned, and stained with DAPI to detect nuclei, anti- $\alpha$-SMA antibody to detect myofibroblasts and anti-CCN2 antibody (10× magnification of dermal tissue). The percentage of fibroblasts within the wound that were $\alpha$-SMA positive, NG2 positive, and both NG2/ $\alpha$-SMA positive was calculated as described in Methods. Note that essentially all cells in the wound area are myofibroblasts. Representative data from $n=4$ wounds from 4 separate animals per time point is shown 
(Fig. 3). Collectively, these results not only support the notion that $\mathrm{CCN} 2$ is an excellent marker of myofibroblast activation in response to fibrotic stimuli, but also suggest that pericytes can significantly contribute to the presence of myofibroblasts within fibrotic lesions.

\section{Discussion}

Elevated, constitutive CCN2 expression is a hallmark of fibrotic disease and can be considered a surrogate marker of fibrosis (Blom et al. 2002; Leask and Abraham 2006). In response to tissue injury, $\mathrm{CCN} 2$ is induced in myofibroblasts (Kapoor et al. 2008). In this report, we extend these studies and show that, in response to the bleomycin-induced model of skin fibrosis, CCN2 is expressed in myofibroblasts. Moreover, pericytes, which are believed to contribute to the total number of myofibroblasts in fibrotic tissue (Hinz et al. 2007; Rajkumar et al. 2006), also express CCN2 and comprise the majority of fibroblasts activated in response to bleomycin. Our data are consistent with previously published data showing that $\mathrm{CCN} 2$ is expressed in pericytes in culture as well as in retinas of diabetic patients (Shiwen et al. 2009; Kuiper et al. 2004). Our data are also consistent with a previous study from our group showing that CCN2, type I collagen protein and mRNAs encoding other fibrotic proteins such as fibronectin are upregulated in cultured pericytes (Shiwen et al. 2009). Our results also support the notion that CCN2 is a faithful marker of fibrogenesis in vivo (Blom et al. 2002; Leask and Abraham 2006). It is interesting to note that recently it was shown that an anti-CCN2 antibody alleviated bleomycin-induced lung fibrosis (Ponticos et al. 2009) and siRNA against $\mathrm{CCN} 2$ reversed $\mathrm{CCl}_{4}$-induced liver fibrosis (Brigstock 2009). Thus CCN2 may be both a marker and a mediator of fibrosis (Grotendorst 1997; Leask and Abraham 2004, 2006). Finally, our data suggest that pericytes are a significant source of myofibroblasts in skin fibrosis. Collectively, our results may be useful in the future for uncovering new strategies aimed at modulating (myo)fibroblast biology during fibrosis.

\section{Materials and methods}

\section{Bleomycin-induced skin fibrosis}

Bleomycin (Sigma) was diluted to $0.1 \mathrm{U} / \mathrm{ml}$ with PBS, and filter sterilized. $100 \mu \mathrm{l}$ of bleomycin or PBS was injected subcutaneously into a single location on the shaved back of C57/BL6 mice once daily for 4 weeks (Yamamoto et al. 1999) Mice were the killed using $\mathrm{CO}_{2}$, and skin was collected for immunohistochemical analysis. Tissue samples used for this experiment were generated in a previously published study (Liu et al. 2009).

Immunofluorescence

Tissue sections $(0.5 \mu \mathrm{m})$ were cut using a microtome (Leica), collected on Superfrost Plus slides (Fisher Scientific), dewaxed in xylene and rehydrated by successive immersion in descending concentrations of alcohol. Tissue sections were then incubated with mouse serum for $30 \mathrm{~min}$, washed with PBS and incubated with primary antibodies for 1 hour at room temperature. Primary antibodies used alone (single immunofluorescence) or in combination (double immunofluorescence) were: rabbit anti-CCN2 (anti-CCN2; 1:100 dilution, Abcam), mouse anti-NG2 (pericyte marker, 1:100 dilution, Chemicon), mouse anti-alpha-smooth muscle actin ( $\alpha$-SMA, 1:100 dilution, Sigma). Double immunofluorescence for $\alpha$-SMA and NG2 was performed using rabbit polyclonal antibody for $\alpha$-SMA (Abcam) and mouse antibody for NG2. Sections were washed with PBS, incubated with appropriate fluorescent secondary antibodies (Jackson Immunoresearch) for one hour at room temperature, washed with PBS, mounted using DAPI and photographed using Zeiss fluorescence microscope and Northern Eclipse software (Empix). Six independent fields were examined per data point.

Sections undergoing double immunofluorescence were photographed at $10 \times$ magnification. To detect number of $\alpha$-SMA, CCN2 or NG2 positive cells, total number of cells/ $\mathrm{mm}^{2}$ were counted. The percentage $\alpha$-SMA, CCN2 and NG2 positive cells $/ \mathrm{mm}^{2}$ were then calculated.

Results are expressed as the mean \pm SEM. $P<0.05$ was considered statistically significant $(*$; Student's t test).

Acknowledgements Our work is funded by the Canadian Institute of Heath Research and the Canadian Foundation for Innovation. A.L is an Arthritis Society (Scleroderma Society of Ontario) New Investigator and a recipient of Early Researcher Award. RT was supported by a Summer Studentship of the Canadian Scleroderma Research Group.

Open Access This article is distributed under the terms of the Creative Commons Attribution Noncommercial License which permits any noncommercial use, distribution, and reproduction in any medium, provided the original author(s) and source are credited.

\section{References}

Blom IE, Goldschmeding R, Leask A (2002) Gene regulation of connective tissue growth factor: new targets for antifibrotic therapy? Matrix Biol 21:473-482

Brigstock DR (2009) Strategies for blocking the fibrogenic actions of connective tissue growth factor (CCN2): from pharmacological inhibition in vitro to targeted siRNA therapy in vivo. J Cell Commun Signal 3:5-18 
Chen Y, Shiwen X, van Beek J, Kennedy L, McLeod M, Renzoni EA, Bou-Gharios G, Wilcox-Adelman S, Goetinck PF, Eastwood M, Black CM, Abraham DJ, Leask A (2005) Matrix contraction by dermal fibroblasts requires TGFbeta/ALK5, heparan sulfate containing proteoglycans and MEK/ERK: Insights into pathological scarring in chronic fibrotic disease. Am J Pathol 167:1699-1711

Desmouliere A, Chaponnier C, Gabbiani G (2005) Tissue repair, contraction, and the myofibroblast. Wound Repair Regen 13:712

Gao R, Brigstock DR (2004) Connective tissue growth factor (CCN2) induces adhesion of rat activated hepatic stellate cells by binding of its C-terminal domain to integrin alpha(v)beta(3) and heparan sulfate proteoglycan. J Biol Chem 279:8848-8855

Grotendorst GR (1997) Connective tissue growth factor: a mediator of TGF-beta action on fibroblasts. Cytokine Growth Factor Rev 8:171-179

Hinz B, Phan SH, Thannickal VJ, Galli A, Bochaton-Piallat ML, Gabbiani G (2007) The myofibroblast: one function, multiple origins. Am J Pathol 170:1807-1816

Holmes A, Abraham DJ, Sa S, Shiwen X, Black CM, Leask A (2001) CCN2 and SMADs, maintenance of scleroderma phenotype is independent of SMAD signaling. J Biol Chem 276:1059410601

Holmes A, Abraham DJ, Chen Y, Shi-wen X, Denton C, Black CM, Leask A (2003) Sp1 is required for elevated CTGF expression in scleroderma fibroblasts. J Biol Chem 278:41728-41733

Kapoor M, Liu S, Huh K, Parapuram S, Kennedy L, Leask A (2008) Connective tissue growth factor promoter activity in normal and wounded skin. Fibrogenesis Tissue Repair 1(1):3

Kuiper EJ, Witmer AN, Klaassen I, Oliver N, Goldschmeding R, Schlingemann RO (2004) Differential expression of connective tissue growth factor in microglia and pericytes in the human diabetic retina. Br J Ophthalmol 88:1082-1087

Lasky JA, Ortiz LA, Tonthat B, Hoyle GW, Corti M, Athas G, Lungarella G, Brody A, Friedman M (1998) Connective tissue growth factor mRNA expression is upregulated in bleomycininduced lung fibrosis. Am J Physiol 275:L365-L371

Lau LF, Lam SC (1999) The CCN family of angiogenic regulators: the integrin connection. Exp Cell Res 248:44-57

Leask A, Abraham DJ (2004) TGF-beta signaling and the fibrotic response. FASEB J 18:816-827

Leask A, Abraham DJ (2006) All in the CCN family: essential matricellular signaling modulators emerge from the bunker. J Cell Sci 119:4803-4810
Leask A, Holmes A, Black CM, Abraham DJ (2003) Connective tissue growth factor gene regulation. Requirements for its induction by transforming growth factor-beta 2 in fibroblasts. J Biol Chem 278:13008-13015

Liu S, Kapoor M, Denton CP, Abraham DJ, Leask A (2009) Loss of $\beta 1$ integrin in mouse fibroblasts results in resistance to a mouse model of skin scleroderma. Arthritis Rheum 60:2817-2821

Ozerdem U, Stallcup WB (2004) Pathological angiogenesis is reduced by targeting pericytes via the NG2 proteoglycan. Angiogenesis 7:269-276

Ponticos M, Holmes AM, Shi-Wen X, Leoni P, Khan K, Rajkumar VS, Hoyles RK, Bou-Gharios G, Black CM, Denton CP, Abraham DJ, Leask A, Lindahl GE (2009) Pivotal role of connective tissue growth factor in lung fibrosis: MAPKdependent transcriptional activation of type I collagen. Arthritis Rheum 60:2142-2155

Rajkumar VS, Shiwen X, Bostrom M, Leoni P, Muddle J, Ivarsson M, Gerdin B, Denton CP, Bou-Gharios G, Black CM, Abraham DJ (2006) Platelet-derived growth factor-beta receptor activation is essential for fibroblast and pericyte recruitment during cutaneous wound healing. Am J Pathol 169:2254-2265

Salvucci O, Maric D, Economopoulou M, Sakakibara S, Merlin S, Follenzi A, Tosato G (2009) EphrinB reverse signaling contributes to endothelial and mural cell assembly into vascular structures. Blood 114:1707-1716

Shiwen X, Rajkumar V, Denton CP, Leask A, Abraham DJ (2009) Pericytes display increased $\mathrm{CCN} 2$ expression upon culturing. J Cell Commun Signal 3:61-64

Shi-Wen X, Renzoni EA, Kennedy L, Howat S, Chen Y, Pearson JD, Bou-Gharios G, Dashwood MR, du Bois RM, Black CM, Denton CP, Abraham DJ, Leask A (2007) Endogenous endothelin-1 signaling contributes to type I collagen and CCN2 overexpression in fibrotic fibroblasts. Matrix Biol 26:625-632

Tomasek JJ, Gabbiani G, Hinz B, Chaponnier C, Brown RA (2002) Myofibroblasts and mechano-regulation of connective tissue remodelling. Nat Rev Mol Cell Biol 3(5):349-363

Van Beek JP, Kennedy L, Rockel JS, Bernier SM, Leask A (2006) The induction of CCN2 by TGFbeta1 involves Ets-1. Arthritis Res Ther $8(2)$ :R36

Wu M, Varga J (2008) In perspective: murine models of scleroderma. Curr Rheumatol Rep 10:173-182

Yamamoto T, Takagawa S, Katayama I, Yamazaki K, Hamazaki Y, Shinkai H, Nishioka K (1999) Animal model of sclerotic skin. I: Local injections of bleomycin induce sclerotic skin mimicking scleroderma. J Invest Dermatol 112:456-462 